\title{
COURTS OF SPECIALIZED JURISDICTION IN AUSTRALIA
}

\author{
Eric Armour Beecroft'
}

The Australian Constitution, ${ }^{1}$ like that of the United States, provides for a threefold division of powers, chapter I providing for the legislature, chapter II for the executive and chapter III for the judicature. Section 7 I under chapter III reads as follows:

"The judicial power of the Commonwealth shall be vested in a Federal Supreme Court, to be called the High Court of Australia, and in such other federal courts as the Parliament creates, and in such other courts as it invests with federal jurisdiction. The High Court shall consist of a Chief Justice, and so many other Justices, not less than two, as the Parliament prescribes."

Section 72 provides that the justices of all such courts shall be appointed by the Governor-General, shall be removable only on an address of both Houses of Parliament, and shall receive a remuneration which shall not be diminished during their term of office. ${ }^{2}$

One might think, from the words of these sections, that the court-creating power which is thereby vested in Parliament is exclusive, that is, that Parliament can create no courts except those which are to exercise "the judicial power of the Commonwealth" and that all federal courts, when created, must conform to section 72 and the other sections of chapter III. It is true that chapter III does limit and control the creation by Parliament of courts exercising "the judicial power of the Commonwealth", 3 but the High Court has recognized another class of tribunals

${ }^{1}$ Commonwealth of Australia Constitution Act, $63 \& 64$ VICr. c. I2 (I900).

${ }^{2} C f$. Art. III, $\S \mathrm{I}$ of the American Constitution: "The judicial power of the United States shall be vested in one Supreme Court, and in such inferior courts as the Congress may from time to time ordain and establish. The judges, both of the Supreme and inferior courts, shall hold their offices during good behavior, and shall at stated times receive for their services a compensation, which shall not be diminished during their continuance in office." infra $\mathrm{p}$.

${ }^{3}$ New South Wales v. The Commonwealth, 20 C. L. R. 54 (I9r5), discussed 
exercising some judicial functions and employing judicial procedure. These tribunals do not, however, in the opinion of the High Court, exercise "the judicial power of the Commonwealth", and therefore do not derive their authority from the provisions of chapter III of the Constitution, nor are they in any way controlled by the provisions of that chapter.

Where, then, do these tribunals derive their constitutional validity? The answer is that they are created under other constitutional powers granted to the Federal Parliament,-for example, the power to regulate trade and commerce with other countries and among the states, the power to tax, the power to make laws with respect to patents and trade marks, immigration and emigration, and conciliation and arbitration for the prevention and settlement of industrial disputes. Section $5 \mathrm{I}$ (xxxix) of the Constitution ${ }^{4}$ reinforces the legislative powers of the Commonwealth just as the "necessary and proper" clause reinforces the powers granted to Congress. These tribunals, then, possess a specialized jurisdiction. They are not concerned with what Blackstone, in the Commentaries, ${ }^{5}$ referred to as "the administration of common justice".

It is with these specialized courts, which are established under clauses other than those of chapter III-one might call them non-chapter III courts-that this paper is concerned. ${ }^{6}$

\section{The Court of Conciliation and Arbitration}

Section $5 \mathrm{I}$ (xxxv) of the Australian Constitution grants to Parliament power with respect to "conciliation and arbitration for the prevention and settlement of industrial disputes extending beyond the limits of any one State". Parliament, therefore, can-

- Sec. 5I (xxxix) : Parliament shall have power to make laws with respect to "matters incidental to the execution of any power vested by this Constitution in the Parliament or in either House thereof, or in the Government of the Commonwealth, or in the Federal Judicature, or in any department or officer of the Commonwealth."

'I BL. Comis. 269.

- This class of tribunals has been recognized in the United States under the rather inappropriate designation of "Legislative Courts." See Ex parte Bakelite Corporation, 279 U. S. 438, 49 Sup. Ct. 4II (I929), where the two classes of courts have been clearly distinguished by the Supreme Court; also FrANKFURTER and Landis, The Business of the Supreme Court (I927) c. IV, and Katz, Federal Legislative Courts (I930) 43 HARv. L. Rev. 894. 
not make any laws with respect to industrial conditions, for most of such power is reserved to the states. It is limited to the one method of dealing with industrial conditions provided for in section $5^{\mathrm{r}}(\mathrm{xxxv})$.

Soon after the establishment of the federal government, Parliament passed the Commonwealth Conciliation and Arbitration Act 1904. Under this Act there was established a Court of Conciliation and Arbitration which, according to section I I of the Act, was to be a "Court of Record". It was to consist of a President appointed by the Governor-General from among the justices of the High Court, entitled to hold office for seven years, eligible for reappointment, and liable to removal only on the address of both Houses of Parliament. ${ }^{7}$ The President was given authority to appoint as his deputy any justice of the High Court or judge of the supreme court of a state. ${ }^{s}$

This court (which I shall call the Arbitration Court) began its work in I905. In the years immediately following, it was necessary for the High Court to decide many cases involving an interpretation of the Arbitration Act and the constitutional provision under which it was authorized. Among the questions involved was that of the real nature of the Arbitration Court and its functions. In making up its mind, or minds, on this matter, the High Court divided sharply.

The first concrete case in which this division occurred was the Bootmakers' case ${ }^{9}$ in I9Io. The Australian Boot Trade Employees Federation had brought a complaint in the Arbitration Court in which they made a certain claim. ${ }^{10}$ The matter was heard by the President, who, after hearing evidence and arguments, drew up the minutes of his proposed award. Before he would attempt to put the award into effect, however, he stated

${ }^{7}$ Sec. 12.

${ }^{8}$ Sec. 14.

Australian Boot Trade Employes Federation v. Whybrow \& Co., ro C. L. R. 266 (1910). In a previous case, Federated Saw Mill Employees'Assoc. v. Moore, \& C. L. R. 465 (1909), substantially the same questions were considered at length for the first time by the High Court, but owing' to the hypothetical character of the case, the opinions of the judges were not regarded as conclusive.

${ }^{10} 4$ Comm. Arbit. Repts. I (I909). 
a case ${ }^{11}$ for the determination of the High Court of the following questions:

"I. Is it competent for this Commonwealth Court under the Federal Constitution to make any award which is inconsistent with any and if so which of the said awards or determinations of the State Wages Boards?

" 2 . Is there in the proposed award any provision or provisions and if so what provision or provisions inconsistent with any and if so which of the awards or determinations of the States Wages Boards, and in what respects?"

A majority of the High Court held that the Arbitration Court had no jurisdiction under section 5 I (xxxv) of the Constitution to make an award inconsistent with a state law. The determination of a Wages Board, empowered by a state statute to fix a minimum rate of wages, might be such a law, depending upon the terms of the statute under which it was made. The awards and determinations of the State Wages Boards in question in the present case had the force of law under the statutes. Mr. Justice Barton pointed out that:

"the Wages Boards are not tribunals of arbitration, but subsidiary legislative bodies deriving their authority from the State legislatures . . The rates of wages, when fixed by the Boards, are to all intents and purposes the law on the subject.' They are as distinct from the judgment of a Court as they are from the award of an arbitrator." 12

This last sentence is the key to the difference of opinion in the court. The majority were unwilling to admit that an award of the Arbitration Court was the result of a legislative act, in other words, that the Arbitration Court was a subsidiary legislative body. If they had so admitted they would have been compelled to concede further, that an award of the Federal Arbitration Court took precedence over any state law including the deter-

"Sec. 3 I (2) of the Arbitration Act I904 provides that "the President may, if he thinks fit, in any proceeding before the Court, at any stage and upon such terms as he thinks fit, state a case in writing for the opinion of the High Court upon any question arising in the proceeding which in his opinion is a question of law."

${ }^{12}$ Suspra note 9, at 289 . 
minations and awards of State Wages Boards, by force of the plain meaning of section Iog of the Constitution. ${ }^{13}$ Such an interpretation would have been repugnant to the habitual "statesrights" attitude of the three judges who formed the majority. Hence this supposedly unthinkable and unwarranted extension of federal powers was avoided by maintaining that the function of the Arbitration Court was judicial and not legislative and that, therefore, its awards were judicial determinations and not legislative enactments.

How confused were the minds of Chief Justice Griffith and Sir Edmund Barton on this issue is very evident in their opinions. ${ }^{14}$ The strong language they used indicates how outraged they were at the very suggestion that a single "judicial" officer of the Commonwealth could render void every state enactment regulating industrial conditions. To approve such a doctrine, they thought, would be to uphold the most despotic power. They both insisted vigorously that the function of an arbitrator is like that of a judge, in that it is for him to declare the law and not to make it. They held out stubbornly for this view in the face of the very lucid and realistic statement of Mr. Justice Isaacs, showing that the Arbitration Court did not declare existing rights and obligations, but actually created new law. ${ }^{15}$

Mr. Justice Isaacs and Mr. Justice Higgins (the latter was President of the Arbitration Court) dissented. The former expressed his disagreement with the theory that the duty of the Arbitration Court was to declare law rather than to make it. What law did it declare? There was no Commonwealth law

${ }^{23}$ Sec. 109: "When a law of a State is inconsistent with a law of the Commonwealth, the latter shall prevail, and the former shall, to the extent of the inconsistency, be invalid."

"See especially supra note 9, at 284, 294 and 297.

${ }^{15}$ Mr. Justice Barton declared that "beyond all question the award is a judicial determination. That, at least, has never been the subject of doubt, whether in a Court or elsewhere." (Supra note 9, at 294); and further: "The Australian Constitution is no less careful than other fundamental laws to clearly separate the judicial from the legislative authority and to define their respective functions, and it is too much to ask us to believe that, by the words used in this power, it has sanctioned their collocation in one and the same authority, and that primarily a judicial one." (Sipra note 9, at 297.) Chief Justice Griffith made this statement: "The legislative and judicial powers of a sovereign state are exercised by different agencies, whose operations are in different planes, and cannot come in conflict with one another." (Supra note 9, at 284.) 
regulating industrial conditions. The Constitution had no specific provisions on the subject. There was no enactment of Parliament on which the rules prescribed by the President of the Arbitration Court were founded. There was, in fact, no statute law which he was called upon to interpret and apply, as an ordinary judicial tribunal would have to do; and the common law admittedly did not bind him. "If then", asked Mr. Justice Isaacs, "his determination is not in the nature of a law, just as is the determination of a Wages Board, by what authority is anyone bound by it?" 16

Mr. Justice Isaacs then distinguished a judicial and a legislative act:

"If the dispute is as to the relative rights of parties as they rest on past or present circumstances, the award is in the nature of a judgment, which might have been the decree of an ordinary judicial tribunal acting under ordinary judicial power. There the law applicable to the case must be observed. If, however, the dispute is as to what shall in the future be the mutual rights and responsibilities of the parties-in other words, if no present rights are asserted or denied, but a future rule of conduct is to be prescribed, thus creating new rights and obligations, with sanctions for nonconformity-then the determination that so prescribes, call it an award, or arbitrament, determination, or decision or what you will, is essentially of a legislative character, and limited only by the law which authorizes it." 17

Mr. Justice Isaacs argued further that the combined effect of section $5^{\mathrm{I}}$ ( $\mathrm{xxxv}$ ) with section $5^{\mathrm{I}}$ (xxxix) of the Constitution was to grant the Arbitration Court the extensive legislative power which he believed it was intended to possess. Here, inevitably,

${ }^{36}$ Supra note 9, at 313 .

${ }^{17}$ Supra note 9, at 318. Mr. Justice Isaacs refers to the similar distinction made by Mr. Justice Holmes in Prentis v. Atlantic Coast Line Co., 2II U. S. $210,226,29$ Sup. Ct. 67,70 (1908). He quotes the statement that "the nature of the final act determines the nature of the previous inquiry." He quotes also with approval from Knoxville v. Knoxville Water Co., 2I2 U. S. I, 8, 29 Sup. Ct. 148, I50 (I909): "The function of rate-making is purely legislative in character, and this is true. whether it is exercised directly by the legislature itself or by some subordinate or administrative body to whom the power of fixing rates in detail has been delegated. The completed act derives its authority from the legislature and must be regarded as an exercise of legislative power." 
he invoked the authority of $M c C u l l o c h v$. Maryland ${ }^{18}$ Mr. Justice Higgins repeated substantially the same views. ${ }^{19}$

The instability of the prevailing doctrine is obvious enough, considering that it was upheld by a mere majority of one. But add to this the wavering and unsettled view of $\mathrm{Mr}$. Justice O'Connor, and it becomes evident that the decision in the Bootmakers' case by no means created a settled doctrine. Mr. Justice O'Connor, though he stood with the majority in this case, admitted that in some circumstances state laws must be disregarded. ${ }^{20}$ It might be proper, he said, in some cases, for the Arbitration Court to ignore state laws in order to make an effective settlement of a dispute. But, beyond that, the power of the court was limited by the word "arbitration" itself.

There is no doubt, as I have already indicated, that the decision in the Bootmakers' case was highly colored by the attitude of the three majority judges toward the extension of federal powers. ${ }^{21}$ Their desire to regard arbitration as attributable to the judicial department rather than to the legislative department was due partly to their preconceptions concerning the separation of powers, but perhaps even more largely to their desire to uphold state authority. This is evident from the concessions made by Mr. Justice O'Connor, from the reluctance of the Chief Justice to say outright that an arbitration award was not a law and from the failure of the majority to give clear reasons for distinguishing

${ }^{18} 4$ Wheat. 316 (U. S. 1819).

${ }^{20}$ In the United States, the precedence of federal administrative orders and rules made by federal boards and commissions over laws and regulations of the states has usually been taken for granted. See, e. g., Houston v. Moore, 5 Wheat. I (U. S. I820); Columbia Wire Co. v. Freeman Wire Co., 7 I Fed. 302 (C. C. Mo. 1895); Looney v. East Texas R. R. Co., 247 U. S. 214, 38 Sup. Ct. 460 (IgI8); and the Transportation Act of Feb. 28, I920, \$402, par. I7, 4I STAT. 456 , at 477 (I92I), 49 U. S. C. A. § I (I0-22) (I929).

so Supra note 9, at 305-307.

${ }^{21}$ As to the principles of "strict construction" which the senior judges followed so consistently in the early days, see Kennedy, Some Aspects of Canadian and Australian Federal Constitutional Law (1930) I5 CoRN. L. Q. 345, 352 et seq.

It may be worth noting that, in the Federal Convention, in I898, both Sir Edmund Barton and Mr. R. E. O'Connor (later to become High Court Justices) opposed the inclusion of the arbitration clause in the constitution, mainly on the ground that it interfered with powers which rightly belonged to the states. See I Records OF AUSTRALIAN FEDERAL CoNvention (1898) I99-202. 
between the effect of the awards of the federal court and the effect of the determinations of State Wages Boards.

The same questions were raised again in an important litigation eight years later. By this time the personnel of the bench had changed considerably. Mr. Justice O'Connor had died and had been replaced by Mr. Frank Gavan Duffy. The number of judges had been increased to seven with the addition of Messrs. Powers and Rich. These three latest appointees were younger men and were less solicitous of "state-rights" than the older judges.

Alexander's case ${ }^{22}$ in I9I 8 arose out of a hearing before the Arbitration Court of an application that the Arbitration Court should impose a penalty on J. W. Alexander Ltd., for the breach of a certain award. Some questions of law were raised which the President of the court stated for the opinion of the High Court. One of these was the contention of the respondent that the Arbitration Court had no power to enforce awards, inasmuch as the President was, under section 12 of the Arbitration Act, appointed for seven years only, contrary to section 72 of the Constitution which provided that every judge of a federal court must be appointed on good behavior. It was also contended that an award of the Arbitration Court was invalid, since such an award was a judicial determination by a federal court, and since the judge of that court was not appointed for life according to the terms of section 72 of the Constitution. The far-reaching character of these questions, involving the very existence of the Arbitration Court itself, led to a lengthy expression of opinion by the justices.

Six of the justices decided that an award of the court was not invalid by reason of the appointment of the President for seven years only. Four of these, including the two junior members of the bench, based their judgment on the ground stated by $\mathrm{Mr}$. Justice Isaacs in the Bootmakers' case, to wit, that the Arbitration Court was not a judicial body, and the conditions specified in section 72 of the Constitution did not apply to it. Mr. Justice

${ }^{2}$ Waterside Workers' Federation of Australia v. J. W. Alexander, Ltd., 25 C. I. R. 434 (1918). 
Duffy did not deny that it was a judicial body, but held that section 72 did not prohibit an appointment for seven years only. It merely prevented removal during the prescribed term of office except on addresses of both Houses of Parliament.

Chief Justice Griffith held to his former view that the Arbitration Court was a judicial body, but by some ingenious juggling of words he maintained that the appointment of a President of the Arbitration Court was not affected by section 72. Section I2 of the Arbitration Act, he pointed out, had provided that the President of the Arbitration Court should be a justice of the High Court, in other words, a person already holding judicial office during good behavior. Furthermore, he said, the word "appoint" in section I2 of the Act meant "assign" or "designate". Therefore section I2 should be read to mean that the Governor-General should "assign" or "designate" a justice of the High Court to be President of the Arbitration Court.

Mr. Justice Barton held strictly to his former view that the Arbitration Court was a court in the strict sense, that part of the judicial power is reposed in it, and that the act creating it must be interpreted in the light of the judicature chapter of the Constitution.

The joint opinion of Justices Isaacs and Rich in this case contains some refinements upon the opinion of the former in the Bootmakers' case. It shows less eagerness to attribute law-making power in the strict sense to the Arbitration Court. The duty of the arbitrator is, of course, not to ascertain and declare rights, but to determine whether new rights claimed ought to be conceded in whole or in part. "But he does not legislate. It is always the statute which gives the arbitrator's opinion efficacy, and stamps his decision with the character of a legal right or obligation." The work of the arbitrator, then, would seem to be, not a direct exercise of the legislative power, but a function ancillary to the legislative power. "The award provides the factum upon which the law operates to create the right or duty." ${ }^{23}$

There is evident in this opinion, as in those of Justices Higgins and Powers, a more liberal attitude toward the doctrine

${ }^{2}$ Supra note 22, at $463-464$. 
of the separation of powers, an attitude which in recent years has also been forced more and more upon the American Supreme Court in dealing with the status of rule-making boards and commissions. There is evident a clearer understanding on the part of the judges of the underlying social and governmental changes which have necessitated the development of new procedures. It is a common habit of the legal mind to attempt to bring every new entity under an old category. Some of the High Court justices, originally a majority, seemed to assume that this new institution, the Arbitration Court, must be brought within one of the three branches of government provided for in the Constitution-legislative, executive or judicial. The name of the court, the functions assigned to it in the Act, the procedure employed by it-all of these features made it appear as a judicial body. It did not occur to the High Court at first to regard it simply as a new type of institution, a new instrument for dealing with new problems, and falling precisely within none of the old categories.

It should be added that, in accordance with the view of the majority of the High Court that the Arbitration Court was not a judicial body, it was decided in Alexander's case that it could not exercise the powers of a court and enforce its own awards.

The function of the Arbitration Court was again considered in Clyde Engineering Co. Ltd. v. Cowburn. ${ }^{24}$ Here the question arose whether an award ${ }^{25}$ of the Arbitration Court, fixing the hours of labor in certain industries at forty-eight, took precedence over the Forty-Four Hours' Act of New South Wales. Again it became necessary to consider the contention that an arbitration award was not a "law of the Commonwealth" within the meaning of section Iog of the Constitution.

The court decided unanimously that the Parliament of a state could not pass an act which was inconsistent with an award of the Arbitration Court. Mr. Justice Isaacs again gave the clearest explanation of the functions of that tribunal:

"The Federal Arbitration Court is not a law-maker, but it is an 'award-maker', just as the Governor-General-in-

${ }^{24} 37$ C. L. R. 466 (I926).

${ }^{25} 20$ Comm. Arb. Repts. 982 (1924). 
Council is an 'order-maker', or a municipal council is a 'bylaw-maker', or a Court of law is a 'rule-maker'. And if Parliament, unable or unwilling,-it matters not which-to legislate in detail or with reference to a specific instance, but having the authority to empower, does empower a named functionary to formulate what he thinks a proper rule, ... . his formulation, though not a law, may be adopted by Parliament so as to be a law." 26

It would appear, then, that the opinion of Mr. Justice Isaacs has become, instead of a minority opinion, as it was in IgIo, the unanimous opinion of the court. ${ }^{27}$

Another case worthy of notice is Australian Commonwealth Shipping Board et al. v. The Federated Seamen's Union. ${ }^{28}$ The applicant in this case asked the Arbitration Court to cancel the registration of the respondent union. ${ }^{29}$ Deputy-President Webb, before whom the matter was brought for hearing, was doubtful of the power of the Arbitration Court to cancel the registration of an organization, since it appeared, from Alexander's case, that the Arbitration Court could not be invested with any part of the judicial power of the Commonwealth. He therefore stated a case for the opinion of the High Court on this and other questions. The court decided that section 60 of the Arbitration Act did not confer judicial power upon the Arbitration Court. It was therefore a valid enactment of Parliament and the Arbitration Court might, as a result, order the registration of an organization to be cancelled. Chief Justice Knox pointed out that in the Jumbunna

${ }^{3}$ Supra note 24, at 494-495. Mr. Justice Starke, who, as counsel, had argued for the invalidity of the awards in Alexander's case, in I9I8, in this case upheld the paramount authority of the federal awards.

${ }^{z}$ It is interesting, in view of the Cowburm decision, to recall the words of Sir Samuel Griffith and Sir Edmund Barton in the Bootmakers' case. The Cowburn decision has brought about the very situation which the former feared when he said: "The notion of any one person or set of persons being set up in a civilized country with authority to supersede or abrogate any law of which he does not approve is to me so extraordinary that I can hardly conceive of any legislature in full possession of its faculties setting up such an institution." Bootmakers' case, supra note 9 , at 284 .

${ }_{3} 36$ C. L. R. 442 (1925).

$\approx$ Sec. 60 of the Arbitration Act gives to the Registrar of the Arbitration Court power to cancel the registration of an organization under certain circumstances. 
Coal Mine case, ${ }^{30}$ years before, it had been decided that the grant of power to register organizations was incidental to the exercise of the power to make laws with respect to conciliation and arbitration, and that the power to deregister was in the same position. Other members of the court said that the employment of some judicial methods and the exercise of some judicial functions did not make the Arbitration Court a judicial body, and that from a constitutional standpoint, its existence and its procedure were justified under the arbitration clause of the Constitution, and it was not controlled by the provisions of chapter III.

The general result of these decisions was to put the Court of Arbitration in the same position as the so-called legislative courts in the United States, deriving its authority from a source other than the judicature chapter of the Constitution.

This situation, however, has been modified by the enactment of the Commonwealth Conciliation and Arbitration Act of 1926. This Act conferred upon the members of the court a tenure on good behavior in accordance with section 72 of the Constitution. ${ }^{31}$ The court, therefore, can now exercise "the judicial power of the Commonwealth" as a federal court created by Parliament under section $7 I$, and its authority is derived from both section $7 I$ and section $5 \mathrm{I}$ (xxxv) of the Constitution. The titles of its members were changed to Chief Judge and Judges in order to emphasize the change that was made in its character. The change was made on account of the widespread belief that the Arbitration Court should have power to interpret its own awards and to enforce penalties for their breach, instead of leaving these functions to police magistrates who were relatively unfamiliar with industrial matters. ${ }^{32}$ These judicial powers have been exercised freely by the judges of the court since the Act of 1926 went into effect. ${ }^{33}$ (I908).

${ }^{30}$ Jumbunna Coal Mine v. Victorian Coal Miners' Ass'n, 6 C. L. R. 309

${ }^{81}$ Sec. 6.

${ }^{32}$ Parliamentary Debates, (House) May 2I, I926, 2233-2238; June I7, 32073268; June I8, 3294-3319; (Senate) June 23, 3366-340r.

${ }^{33}$ A special arbitration tribunal, modeled on the Court of Conciliation and Arbitration, to determine claims as to salaries and terms of employment in the Public Service, was established under the Arbitration (Public Service) Act of 1920. Such matters had formerly, under the Arbitration (Public Service) Act of IgIr, been dealt with by the Court of Conciliation and Arbitration. 


\section{The Income Tax Assessment Boards}

The Income Tax Assessment Act of 1922 provided for the establishment of boards of appeal for the purpose of dealing with appeals and references from the Commissioner of Taxation. A Board of Appeal was empowered under the Act to hear cases referred to it by the Commissioner, ${ }^{34}$ and to make such an order as it thought fit and either to reduce or to increase the assessment. $^{35}$ A taxpayer was allowed the right to appeal from the decisions of the Commissioner either: (a) to the Figh Court or the supreme court of a state (where the objection raised only questions of law); or (b) to the High Court or a supreme court or a Board of Appeal (where the objection raised questions of fact).$^{36}$ An order of a board on questions of fact was to be final and conclusive on all parties, ${ }^{37}$ and an order by a court was to be final and conclusive with respect to both law and fact except as provided in section $5 \mathrm{I}$, sub-sections 6 and $8 .^{38}$

Section 28, sub-section I of the same Act provided that, where a business is controlled principally outside of Australia, the person carrying on the business in Australia should be assessable to income tax on such percentage of the total receipts of the business as the Commissioner in his judgment thought proper. Section 28, sub-section 3, provided that, on the request of a taxpayer who was dissatisfied with the decision of the Commissioner under this section, "his case" would be referred to a Board of Appeal.

An important case arose under this latter section in I925, the British Imperial Oil Co. Ltd. v. The Federal Commissioner of Taxation. $^{39}$ On the hearing of the appeal, a case was stated by

35 Sec. 44 (I).

${ }^{3}$ Secs. $44(2)$ and $5 I(I)$.

${ }^{30}$ Sec. $50(4)$.

${ }^{37}$ Sec. $5 \mathrm{r}(2)$.

${ }^{33}$ Sec. $5 \mathrm{I}$ (3). Sec. $5 \mathrm{I}$ (6) reads: "On the hearing of the appeal the Board shall, on the request of a party, and the Court may, if the Court thinks fit, state a case in writing for the opinion of the High Court upon any question arising in the appeal which in the opinion of the Board or of the Court, as the case may be, is a question of law." Sec. 5I (8) reads: "An appeal shall lie to the High Court, in its appellate jurisdiction, from any order made under sub-section ( $I$ ) of this section except a decision by the Board on a question of fact."

${ }^{39} 35$ C. L. R. 422 (1925). 
the board for the opinion of the High Court. ${ }^{40}$ The appellant contended that sub-section 3 of section 28 was invalid, because Parliament had attempted by sections 44,50 and $5^{I}$ of the Act to confer a part of the judicial power of the Commonwealth upon a Board of Appeal, which, as constituted by section 4I was not a court upon which that power could be conferred, section $4 \mathrm{I}$ subsection 4 having provided for a seven-year tenure of office for the members of such a board. Appellants argued further that since section 28 , sub-section 3 was not severable from the rest of section 28 , the whole section was invalid, and that therefore they would not be liable to the assessment in question.

It will be observed that this was the same ground on which the power of the Arbitration Court to enforce its awards was challenged in Alexander's case. Alexander's case was therefore invoked in this case as authority for the principle that the judicial power of the Commonwealth could only be vested in courts, that is, to use Chief Justice Knox's words, "courts of law in the strict sense". And members of such courts must be appointed for life subject to the power of removal contained in section 72 of the Constitution.

Of the Board of Appeal, Chief Justice Knox observed:

"the power conferred on the Board of determining questions of law, the association of the Board as a tribunal of appeal with the High Court and the Supreme Court of a State, and the provision for an appeal to the High Court in its appellate jurisdiction from any order of the Board, except a decision on a question of fact, in my opinion establish that the expressed intention of Parliament was to confer on the Board portion of the judicial power of the Commonwealth, which at any rate includes the power to adjudicate between adverse parties as to legal claims, rights and obligations, and to order right to be done in the matter."

The court decided without dissent (Higgins, J., took no part in the decision) that the Board of Appeal which Parliament purported to create was not lawfully constituted in the form provided for in the Assessment Act.

to See sec. 5I (6), quoted supra note 38 . 
There was undoubtedly a difference between the constitution of the Board of Appeal under the Assessment Act and that of the Arbitration Court as it existed at the time of Alexander's case, a sufficiently marked distinction to account for the difference in the attitude of the High Court in the two cases. The Arbitration Court, it is true, possessed final and conclusive power in making awards, but such awards were in no sense adjudications of rights under existing laws. On the other hand, the Boards of Appeal, in making their determinations, were bound by the provisions of a detailed statute, which specified the rights and obligations of the taxpayers. Moreover, from the awards of the Arbitration Court, there was no appeal to the High Court "in its appellate jurisdiction" " ${ }^{11}$ as in the case of the Boards under the Assessment Act.

As a direct result of the decision in the British Imperial Oil Co. case, the Income Tax Assessment Act was amended in 1925. Parliament, apparently, endeavored with the greatest care to steer clear of the judicial rocks which had been charted in that case. ${ }^{42}$ "Boards of Appeal" were renamed "Boards of Review", and the seven-year tenure of office was retained. ${ }^{43}$ Section 44 of the principal Act was amended to read:

"A Board of Review shall have power to review such decisions of the Commissioner, Assistant Commissioner, or Deputy Commissioner as are referred to it by the Commissioner under this Act . . . and the decisions of the Board of Review shall, for all purposes (except for the purposes of sub-sec. (4) of sec. 5o and sub-sec. (6) of sec. 5 I of this Act) be deemed to be assessments, determinations or decisions of the Commissioner."

A taxpayer dissatisfied with a decision of the Commissioner was allowed to request the Commissioner: (a) to refer the decision to a Board of Review for review, or (b) to treat his objection as an appeal and to forward it either to the High Court or to the supreme court of a state. ${ }^{44}$ On such a reference or appeal, the

4It was so held in the Tramways case (No. I), 18 C. L. R. 54 (I914).

- Parliamentary Debates, (House) July I7 and Sept. I7, 1925, 1275-1279 and 2515-2530; (Senate) Sept. 23, 1925, 2604-2609.

iSec. $4 \mathrm{I}$ (I) and (4) of the amended Act.

"Sec. $50(4)$. 
board, or court, as the case might be, might confirm, reduce, increase or vary the assessment. ${ }^{45}$ In the case of appeals to a court, they were to be dealt with by a single justice. ${ }^{40}$ An appeal was allowed to the High Court from any decision of a Board which, in the opinion of the High Court involved a question of law. ${ }^{47}$ An appeal was also allowed to the High Court in its appellate jurisdiction from any order made by a justice of the High Court or a supreme court of a state. ${ }^{48}$

Having made these alterations in the constitution and powers of the boards, Parliament, by sections 18 to 21 of the amending Act, purported to validate the decisions of the body of persons de facto acting as a Board of Appeal under the earlier Act by providing that all such decisions should be deemed to have been decisions of a Board of Review given in pursuance of the provisions of the later Act, and by providing that the Commissioner or the taxpayer might appeal to the High Court from such a decision (as if it were a decision of a Board of Review).

By virtue of this latter provision the case of the Federal Commissioner of Taxation $v$. Munro ${ }^{49}$ came before the High Court. It was an appeal under section $5 \mathrm{I}$, sub-section 6 of the Income Tax Assessment Act of 1925, from a decision of a Board of Appeal constituted by the Act of 1922. Thus, it involved a question as to the validity of the new provisions for the Board of Review. ${ }^{50}$ It was contended that the Act of 1925 , like that of I922, purported to confer on the Board of Review part of the judicial power of the Commonwealth, which by sections $7 \mathrm{I}$ and 72 of the Constitution could be vested only in a court possessing a life tenure. The entire court, with the exception of Chief Justice Knox, rejected this argument, distinguished the Act of I925 from the former Act and decided that the powers which it, by sections 44, 50 and 5I, purported to confer on the Board of Review were

${ }^{45}$ Secs. 5 I (4) and $51 A(5)$.

${ }^{10}$ Sec. 5 I $A(2)$.

${ }^{4} \mathrm{Sec} .5 \mathrm{I}(6)$.

${ }^{49}$ Sec. 5 I $A$ (IO).

48 C. L. R. 153 (1926).

${ }^{80}$ There was a preliminary argument by counsel as to whether $\S$ I8 was invalid as authorizing a thing which was contrary to the Constitution. This argument was ignored by most of the court. 
not part of the judicial power of the Commonwealth and therefore not invalid. The Chief Justice believed that, since the Board of Review was to adjudicate in contests between parties (that is, the taxpayer and the officer representing the Commonwealth) to determine their respective rights under the law, and since a right of appeal to a court of law was allowed, the power exercised by the board was judicial power and therefore unconstitutional.

Mr. Justice Isaacs insisted that the difference in nature between the new board and the old was "the difference between daylight and dark". The former was clearly intended by Parliament to exercise "judicial power". That intention was clear from the constitution of the tribunal. Not so with the new board. Mr. Justice Isaacs made a detailed analysis of the provisions of the Act, pointing out the punctilious care which Parliament had exercised in making the Board of Review conform to the opinion of the court.

"Instead of assimilating the Board to the Court, as in the old sec. 44 , the Board in the new sec. 44 is assimilated to the Commissioner . . . The Crown is bound by all opinions of the Board on pure matters of fact-that is, on true administration of the law-but as to law, the Court and not the Board is to determine. The appeal being given to the Court in its original jurisdiction only-which is manifest when sec. 50 (4) (b) and sec. 5 I A (2) and (Io) are compared-it follows necessarily that the Board's decision is not intended to be an exercise of the judicial power." 51

Mr. Justice Isaacs quotes Lord Haldane as saying that "the tendency of modern legislation has recently been to entrust to many who are prima facie only administrative officers, functions which have some judicial attributes at all events, although they remain primarily administrators".52 The main purpose in this case, says Mr. Justice Isaacs, is an executive purpose, the enforcement of the tax legislation. The decisions of the Board of Review may very appropriately be designated by Lord Haldane's term, "administrative awards". What appears to be judicial conduct is merely the incidental determination in a judicial manner

${ }^{1}$ Sispra note 49 , at 183 .

Everett v. Griffiths, [192I] A. C. 63I, 659. 
of facts, for the purpose of carrying out executive functions in a just way.

Mr. Justice Higgins repeated with approval the argument of the Commissioner's counsel to the effect that Parliament had power under section $5 \mathrm{I}$ (ii) of the Constitution to make laws "with respect to taxation", which, combined with the ancillary power granted in section $5 \mathrm{I}$ (xxxix), gave Parliament power to create bodies which were not courts within the meaning of chapter III of the Constitution. ${ }^{53}$ Parliament could devise any machinery which it thought fit to assist the Commissioner in his functions in respect to taxation. "The board", he said, "ought to be treated as a mere piece of administrative machinery."

One other case under this Act should be mentioned. In I927, an appeal from the Board of Review was brought, under section 5I, sub-section 6, before Mr. Justice Starke of the High Court. ${ }^{54}$ In giving judgment $\mathrm{Mr}$. Justice Starke stated that the board, in its proceedings, does not exercise the judicial power of the Commonwealth, but an administrative function, namely, that of reviewing the Commissioner's assessments. An appeal from such a Board is therefore a proceeding in the original jurisdiction of the High Court, and the parties to the appeal are not limited to the material which was before the Board, but are entitled to adduce such evidence as is relevant in support of, or in answer to, the appeal. ${ }^{55}$

\section{The Inter-State Commission}

Section IOI of the Constitution provides that

"There shall be an Inter-State Commission, with such powers of adjudication and administration as the Parliament deems necessary for the execution and maintenance,

\footnotetext{
53 On the same ground, he believed the Boards of Appeal also to have been validly created under the Act of 1922 .

54 Federal Commissioner of Taxation v. Lewis Berger \& Sons, Ltd., 39 C. L. R. 468 .

w In considering a similar appeal from a Board of Review in I928, the High Court held that the whole of the decision was open to review, and not merely the question of law, since the case was within the original jurisdiction of the High Court. Ruhamah Property Co., Ltd., v. Federal Commissioner of Taxation, 4 I C. L. R. I48 (1928).
} 
within the Commonwealth, of the provisions of this Constitution relating to trade and commerce, and of all laws made thereunder."

Section I03 provides that the members of this commission shall be appointed by the Governor-General, shall hold office for seven years, shall be removable only on the address of both Houses of Parliament, and shall not have their remuneration diminished during their continuance in office.

In I912, Parliament passed the Inter-State Commission Act, Part V of which, entitled "The Judicial Power of the Commission", constituted the Inter-State Commission a court of record with power to grant injunctions. In I9I5, an order was issued by the commission, on the complaint of the Commonwealth, enjoining the state of New South Wales from taking certain action under its Wheat Acquisition Act of r9I4. New South Wales appealed to the High Court, ${ }^{56}$ challenging the jurisdiction of the commission to make such an order. It was contended that the effect of the provisions of Part V of the Inter-State Commission Act was to create a court, that such a court could not be validly created by Parliament, because it did not conform to the provisions of chapter III of the Constitution, and that consequently Part V of the Act was invalid. This contention was upheld by a majority of the High Court. The majority believed that any federal court must conform to section 72 of the Constitution which provided for a life tenure of judges, and that sections IOI and ro2 could not be read as exceptions to that provision. Section IO3 of the Constitution, in the opinion of the court, suggested that the intention of the Constitution was not to create a court. Chief Justice Griffith stated that

"the functions of the Inter-State Commission contemplated by the Constitution are executive or administrative, and the powers of adjudication intended are such powers of determining questions of fact as may be necessary for the performance of its executive or administrative functions, that is, such powers of adjudication as are incidental and ancillary to those functions." 57

o7 Supra note 56 , at 64 . 
Justices Barton and Gavan Duffy disagreed with this decision, holding that the wording of sections IOI-IO3 of the Constitution clearly assigned to Parliament the power to decide what kind of adjudicatory or administrative functions were necessary to equip the commission for the execution and maintenance of the provisions indicated. The determination of Parliament could not be questioned in the High Court.

Thus the majority in this case established the highly important rule that chapter III of the Constitution contains a gift of the whole judicial power of the Commonwealth, and that section Ior must therefore deal only with power other than judicial power. ${ }^{58}$ The High Court has held consistently to this interpretation.

\section{The Deportation Board}

Section $8 \mathrm{~A}$ of the Immigration Act, as amended in 1920 , provides for the deportation from Australia of certain classes of immigrants and sets up for that purpose a board of three members with power to recommend such deportation to the Minister for Home and Territories. If the board recommends that a person be deported, "the Minister may make an order for his deportation". This, in effect, makes the order of the minister final.

In I923, Michael O'Flanagan and John J. O'Kelly went to Australia from Ireland. After they had been arrested on a charge of being engaged in seditious enterprises, they were summoned to appear before the above-mentioned board to show cause why they should not be deported. The two immigrants

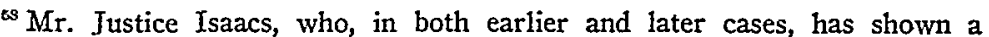
deeper insight into the implications of the modern developments in administrative law than most of the justices, appears in this case as the champion of the separation of powers. His opinion is one of the few in the Australian reports which contains an abstract formulation of a theory of the separation of powers. He points out that the Constitution has "delimited with scrupulous care the three great branches of government," and quotes Chief Justice Marshall in Wayman v. Southard, Io Wheat. I, 46 (U. S. 1825): "The difference between the departments undoubtedly is, that the legislature makes, the executive executes, and the judiciary construes the law." "That describes," says Mr. Justice Isaacs, "the primary functions of each department, though there may be incidents to each power which resemble the other main powers but are incidents only." 
applied to the High Court ${ }^{59}$ for an injunction against the members of the board, restraining them from proceeding further in respect to the summons to appear before the board. One of the grounds upon which they relied was that section $8 \mathrm{~A}$ was invalid because it attempted to vest in the board a portion of the judicial power of the Commonwealth which could be exercised only by the High Court or other federal courts created under chapter III of the Constitution.

The High Court decided that the board was not a judicial tribunal with power to give a decision declaring a right or obligation. Its functions were ministerial. The creation of such a board was within the power of the Commonwealth Parliament to make laws with respect to immigration and emigration, conferred by section $5^{1}$ (xxvii) of the Constitution. ${ }^{60}$

\section{Territorial Courts}

In I9I 5, a case was stated for the opinion of the High Court by the Central Court of Papua, a territory of the Commonwealth. ${ }^{61}$ In the course of the proceedings, on petition of the accused, the case was treated as an appeal from the conviction. It was contended for the accused that he was entitled to a trial by jury on an indictment for an offence against a law of the Commonwealth under section 80 of the Constitution. The court held, however, that section I22 of the Constitution, granting power to (1923).

5 Rex v. Macfarlane et al. sub nomine Ex parte O'Flanagan, 32 C. L. R. 518

This decision was followed in Ex parte Walsh and Johnson; In re Yates, 37 C. L. R. 36 (1925), in which section 8AA of the Immigration Act of I90I1925, providing for the use of the same procedure in deporting persons who menaced industrial peace in Australia, was declared to be a valid exercise of the legislative power conferred by $\$ 5 I$ (xxvii) of the constitution. $C f$. the following United States cases: Fong Yue Ting v. United States, I49 U. S. 698, I3 Sup. Ct. 1016 (I893) ; Unitted States v. Sing Tuck, 194 U. S. I6r, 24 Sup. Ct. 62I (I904); United States v. Ju Toy, I98 U. S. 253, 25 Sup. Ct. 644 (Ig05); $\mathrm{Ng}$ Fung Ho v. White, 259 U. S. 276,42 Sup. Ct. 492 (Ig22). Cf. also Ex parte O'Brien [1923] 2 K. B. 361; Union Government v. Fakir, [1923] So. Afr. Rep. App. Div. 466 .

ot Rex. v. Bernasconi, Ig C. L. R. 629 (IgI5). Sec. 1 of Ordinance No. VIII of Igog of Papua provided that the Central Court must, under certain circumstances, reserve any question of law which arose in the trial of an accused person, for the consideration of the High' Court. Sec. 43 of the Papua Act of 1905 expressly granted an appeal to the High Court. 
Parliament to make laws for the government of a territory, was not restricted by section 80 of the Constitution.

"In my judgment", said Chief Justice Griffith, "chapter III (of the Constitution) is limited in its application to the exercise of the judicial power of the Commonwealth in respect of those functions of government as to which it stands in the place of the States, and has no application to the territories." 62

This opinion seemed to make it clear that none of the sections of chapter III would apply to a territory, and that no court established in any territory would be a federal court from which an appeal would lie to the High Court under section 73 of the Constitution. In I9I8, however, an appeal from the decision of a special magistrate in the Northern Territory was brought to the High Court, ${ }^{63}$ on the assumption that his court was a federal court within the meaning of section 73 of the Constitution. Chief Justice Griffith, in delivering judgment, found it unnecessary to discuss or decide this question, saying merely that the contention was open to grave doubt.

By the Judiciary Ordinance of I92I-I $922,{ }^{64}$ made under the authority of the New Guinea Act of I920, section I4, a Central Court was established for the mandated territory of New Guinea, and an appeal was allowed to the High Court. The New Guinea Act had been passed under the authority of section 122 of the Constitution. In a case arising in $1924,{ }^{65} \mathrm{Mr}$. Justice Isaacs showed that there was a connected chain of authority, starting with the Imperial Treaty of Peace Act of $1919,{ }^{66}$ which empowered the King to accept the mandate for Australia, and leading to the Ordinance of I 922 which endowed the court with the necessary appellate jurisdiction. The mandate ${ }^{67}$ had provided that the

${ }^{2}$ Supra note 6r, at 635 .

${ }^{\infty}$ Mitchell v. Barker, 24 C. L. R. 365.

* Ordinance No. 3 of I921, cl. 7 , and No. 22 of I922, cl. 24; see II CoMM. Stat. Rules 276 (Ig2I)), and 12 ibid. 400,415 (I922).

* Mainka v. Custodian of Expropriated Property, 34 C. L. R. 297 (I924).

${ }^{c 8} 9$ \& Io Geo. V, c. 3 (I9I9).

or The mandate was made Dec. 17, 1920, by the League of Nations Council, and recited that His Majesty, for and on behalf of the Government of Australia, had agreed to accept it. 
Commonwealth should have "full power of administration and legislation over the territory . . . as an integral portion of the Commonwealth of Australia . . ." Hence the Central Court in question is a federal court, though not under the sole authority of section I22.

Even after the Mainka case, therefore, the question remained unsettled whether a court established in a territory under the sole authority of section 122 is a federal court from which an appeal lies to the High Court under section 73 of the Constitution.

Porter v. The King; Ex parte $Y e e^{68}$ in 1926 , raised the question again, in an appeal from the Supreme Court of the Northern Territory. It was contended, under the authority of Rex v. Bernasconi, that the Supreme Court of the Northern Territory was not a federal court from which an appeal would lie to the High Court under section 73, since the judge had not a life tenure, and since the Act of $19 \mathrm{ro}^{69}{ }^{69}$ which authorized the creation of the court, was enacted under section I22 of the Constitution. Mr. Justice Isaacs and three other justices derived from the Bernasconi case the general principle that section 122 granted a plenary authority to the Commonwealth Parliament unlimited by the judicature sections of the Constitution. In their opinion, therefore, Parliament may, under section I22, confer at will appellate jurisdiction from a territorial court. The Bernasconi case was taken to mean that the judicial power of the Commonwealth was that of the Commonwealth proper, that is, the area included within the states, not that of the territories. It followed that, with an appropriate Parliamentary enactment, such as the Act of I9Io was deemed by the majority judges to be, the High Court was competent to entertain appeals from territorial courts. ${ }^{70}$

${ }^{\infty} 37$ C. L. R. 432 (1926).

Northern Territory (Administration) Act, sec. I3. The court was created by the Supreme Court Ordinance of I9II made under the authority of the Act of igio. See 3 Coms. Stat. Rules 425 (IgII).

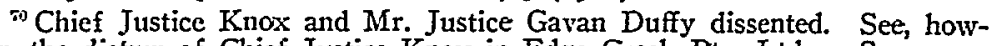
ever, the dictum of Chief Justice Knox in Edge Creek Pty. Ltd. v. Symes, 43 C. L. R. 53 (1929), in which he holds that the Central Court of New Guinea is not a federal court from which an appeal would lie to the High Court under $\$ 73$ of the Constitution.

The courts established by Congress in the territories of the United States, even including Alaska, Porto Rico and Hawaii, have a limited tenure and are not 
Here the matter remains. It seems to be fairly definitely settled that any territorial court is to be regarded as created under the plenary powers conferred to that end upon Parliament in section I22 of the Constitution, and that such courts need not conform in either their constitution or their procedure to the provisions of chapter III.

\section{Public Service Tribunals}

The Commonwealth Public Service Act of 1922, as amended in 1924 and 1928, provides for the control of the civil service of the Commonwealth. ${ }^{71}$ It sets up a Board of Commissioners with wide powers over appointments and promotions and over the organization of the departments. ${ }^{72}$

Section 50 of the Act, as amended in I924, provides that the permanent head of any department in which a vacancy occurs may transfer or promote an officer to fill the vacancy, such promotion being provisional, pending confirmation by the board, and subject to a right of appeal to the board by other officers with claims to promotion. In case of such an appeal, "the Board shall make full inquiry into the claims of the appellant, and those of the officer provisionally promoted, and shall determine the appeal." No further appeal is provided for.

The Act also sets up a procedure for dealing with offences by officers of the public service. In the case of minor offences, the decision of the chief officer of the department, imposing the penalty authorized by the Act, is final. ${ }^{73}$

Where offences are serious, a more elaborate procedure is adopted. Where there is reason to believe that an officer (other

regarded as created under Art. III of the Constitution. See American Insurance Co. v. Canter, I Pet. 5II, esp. at 546 (U. S. I828); also United States v. Fisher, I09 U. S. I43, 3 Sup. Ct. I54 (I883) ; MaAllister v. United States, I4I U. S. I74, II Sup. Ct. 949 (I89I). The United States Court for China and the consular courts are also "non-article III" courts, created under the powers conferred upon Congress respecting treaties and commerce with foreign countries. In re Ross, I40 U. S. 453. II Sup. Ct. 897 (I89I); Fleming v. United States, 279 Fed. 613 (C. C. A. 9 th, I922). IgI8.

77 This Act superseded the' Commonwealth Public Service Act of 1902-

72 This board is empowered to summon witnesses, to compel testimony on oath and to require the production of documents. See $\S$ Ig (I), (4).

${ }^{73}$ Sec. 55 (2). 
than an officer of the first or second division of the service) has committed an offence, a charge may be laid against him before the chief officer of the department. The accused officer shall receive a copy of the charge, and shall be directed to reply in writing, admitting or denying the truth of the charge, and giving any explanation he wishes. The chief officer, after consideration of the reports relating to the charge and the reply, if any, of the officer charged, may, if he finds the charge sustained, impose certain penalties. Where the punishment imposed is other than a fine not exceeding $\mathfrak{f}_{2}$, an appeal is allowed to an Appeal Board. The Appeal Board may confirm, annul, or vary the decision of the chief officer, and its decision, with one exception, ${ }^{74}$ shall be final.

A different procedure is prescribed for offences by officers of the first or second division of the service. ${ }^{35}$ The Minister or permanent head of the department may suspend an officer who is charged with an offence and report the charge to the Board of Commissioners. If the officer does not in writing admit the truth of the charge, the Board of Commissioners shall appoint a Board of Inquiry to inquire into the matter and report to the Board of Commissioners its opinion. If the charges are admitted or sustained by the opinion of the Board of Inquiry, the Board of Commissioners may make such recommendations as to punishment as it thinks fit to the Governor-General. The Governor-General may then dismiss the officer from the service, or impose any other suitable penalty. If the charges are found to be untrue by the Board of Inquiry, the suspension shall be removed at once. ${ }^{76}$

"The exception is that, when the Appeal Board considers that the officer should be dismissed, his case shall be referred to the Board of Commissioners. See $\$ 55(3),(4)$.

$\pi$ Sec. 56 .

${ }^{70}$ Sec. 57 (I) provides that in proceedings before a Board of Inquiry or a Board of Appeal, both the officer and the charging authority may be represented at the hearing by counsel who may examine witnesses and address the board. Sec. 57 (2) reads: "It shall be the duty of the Board of Inquiry or Appeal Board to make a thorough investigation without regard to legal forms and solemnities, and to direct itself by the best evidence which it can procure or which is laid before it, whether the evidence is such as the law would require or admit in other cases or not." Sec. 58 confers on the boards the power to summon witnesses, take evidence on oath and require the production of documents, providing that no person will be required to answer questions which would tend to criminate him. 
There are several observations to be made as to the nature and functions of these tribunals. It will be noted that the Board of Commissioners, the Board of Inquiry, the Appeal Board and the chief officer all have power to make determinations as to important legal rights and obligations of officers. In the case of appeals to the Appeal Board, its decisions are final (with the exception noted above), as are the decisions of the chief officer in minor offences and in more serious offences where the punishment is a small fine. Though the offences in question are statutory (defined in section 55, sub-section I of the same Act), there is no appeal to a higher court. The decisions of the Boards of Inquiry dealing with offences committed by officers of the first and second divisions are not final, since the Board of Commissioners and the Governor-General are empowered to exercise their discretion regardless of the opinions of the Boards of Inquiry. The decisions, on appeal, of the Board of Commissioners on questions of promotion and transfer are also final. In no case is there judicial review of the decisions of these bodies.

The work of these various public service tribunals is largely judicial in character, and judicial procedure is employed. Yet they do not exercise part of "the judicial power of the Commonwealth". It may be said that Parliament has created these tribunals, not under chapter III of the Constitution, but under its power to make laws "incidental to the execution of any power vested . . . in the Government of the Commonwealth or in any department or officer of the Commonwealth," 77 or under its power to make laws concerning the appointment of officers of the executive government. ${ }^{78}$ Unlike the previous creations of Parliament which have been discussed, the constitutional validity of these tribunals has never been challenged in the courts.

\section{Courts of Marine Inguiry}

The creation of the Courts of Marine Inquiry, under the Navigation Act of 1912, raises a perplexing question which has not been settled. The Act confers on these courts power to make

"Sec. 5 I (xxxix).

${ }^{78}$ Sec. 67. 
inquiry as to all casualties affecting ships and as to charges of incompetency or misconduct on the part of masters or officers. ${ }^{79}$ Such inquiries shall be undertaken at the request of the Minister for Trade and Customs, ${ }^{80}$ and the court is required to forward its decision with notes of the evidence to the Minister. ${ }^{81}$ But, in addition to this mere power of inquiry, a Court of Marine Inquiry is given such powers and is constituted in such a way as to make it appear to be a court exercising ordinary judicial power. It is provided that it "shall be a Court of Record and shall have jurisdiction to hear and determine appeals, charges, complaints, inquiries and references under this Act." 82 It may "have all the powers of a Court of summary jurisdiction in the State in which it sits". ${ }^{83}$ It may award costs, ${ }^{84}$ cancel or suspend the certificate of a ship's officer, ${ }^{85}$ and commit an officer to prison for failure to deliver up a certificate. ${ }^{86}$ It therefore has power to determine legal rights and to enforce penalties. No provision is made, however, that the members of the court must have a life tenure of office. $^{87}$

In view of these apparently conflicting provisions, and in view of previous decisions of the High Court, the question arises as to whether a Court of Marine Inquiry is a court exercising "the judicial power of the Commonwealth". If it is intended to be such a court, is the Act creating it unconstitutional in so far as it fails to provide for a life tenure? This question was argued at length by counsel in Rex v. Turner in $1927 .{ }^{88}$ But as it was not the real question at issue, the High Court was able to decide the case without attempting to settle it. In view of the doctrine laid down in Alexander's case, it would seem that if the question

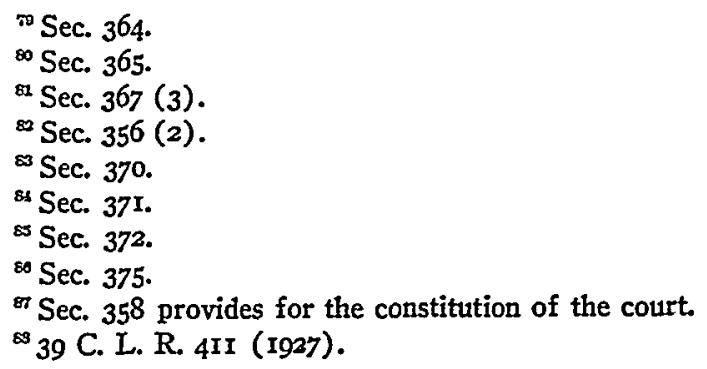


were presented squarely to the High Court, the Courts of Marine Inquiry would be denied the power to enforce penalties, though such power is conferred on them by the Act. Their remaining functions as inquiring bodies with power to summon witnesses, etc., would remain intact, as being authorized under the interstate trade and commerce clause of the Constitution. ${ }^{89}$ Parliament could then, if it wished, create such courts with a life tenure to exercise full judicial power.

\section{Some Other Specialized Tribunals}

The Customs Act of I9OI and the Excise Act of the same year provide for settlement by the Minister of Customs of disputes with reference to any contravention of the Acts. ${ }^{90}$ The Minister may "impose, enforce, mitigate or remit any penalty or forfeiture" and "every such order shall be final and without appeal". In such cases he may summon parties and witnesses, take evidence on oath and require the production of documents.

Under the Patents Act of $1903,{ }^{91}$ the Commissioner of Patents is empowered to accept or refuse specifications for patents. In case of refusal to accept specifications, an appeal is allowed to the High Court or the supreme court of the state in which the Patent Office is situated. If there is opposition to the granting of the patent, the Commissioner must hear and decide the case, and any party aggrieved may appeal from his decision to the High Court or the supreme court of the state. On such an appeal, the High Court or supreme court may hear the applicant and any opponent who, in the opinion of the court, is entitled to be

${ }^{\infty}$ Secs. 5I (I) and 98.

${ }^{\infty}$ Customs Act, Part XV, §§ 265-269; Excise Act, Part XIII, §§ I55-I59. A Court of Customs Appeals was established in the United States by the PayneAldrich Act of Aug. 5, I909, 36 STAT. IO5 (IgrI), 28 U. S. C. A. \$30I (1928). Its judgments are final except that, under the Act of Aug. 22, 1914, 38 STAr. 703 (1915), 28 U. S. C. A. \$ 308 (I928), the Supreme Court has appellate jurisdiction in cases involving the interpretation of the Constitution or treaties. It is a "legislative court," created under the power of Congress to lay and collect duties. Ex parte Bakelite Corp., 279 U. S. $438,458,49$ Sup. Ct. 4II, 416 (1929).

${ }^{22}$ Secs. 43-47, 57-59. The history of the movement to establish a patent court in the United States is given in FRANKFURTER AND LANDIS, op. cit. supra note 6 , at 174-I84. 
heard, and may determine whether the grant ought or ought not to be made.

A somewhat similar procedure is set up under the Trade Marks Act of $1905 .^{92}$ This Act empowers the Registrar of Trade Marks, and on appeal from him, the Attorney-General or Solicitor-General, to decide upon applications for trade marks. Provision is made for the hearing of interested parties in case there is opposition to the acceptance of the application. This, in effect, is a power to decide important matters of both law and fact. An appeal is allowed to the High Court from both the Registrar and the law officer. ${ }^{93}$ Practically the same procedure is provided in the Designs Act of $1906^{\circ 4}$ for the registering of designs.

One other instance should be mentioned. Before 1927 appeals in cases of land assessments were allowed only to the courts. In that year, Parliament amended the Land Tax Assessment Act ${ }^{95}$ to provide for Boards of Valuation and a system of appeals similar to that established under the Income Tax Assessment Act of 1925, which I have already described.

There is no need to try to account here for the rapid growth of specialized courts. Numerous writers in recent years have stressed their increasing importance in modern government and have speculated upon the urgent problems to which they have given rise. ${ }^{96}$ Such tribunals were unnecessary in an age when governments did little else than maintain order. Today they are

Secs. 33-35, 42-45.

${ }^{\circ}$ As to the duty of the High Court in hearing appeals from the registrar or the law officer, see A. Ferguson \& Co. v. D. Crawford \& Co., to C. L. R. 207 (IgIo), and A. F. Pears, Ltd., v. Pearson Soap Co., 37 C. L. R. 340 (I925). Secs. 23-25.

* Sec. 44 of the amended Act. The Commonwealth Parliament has recently. cstablished a Federal Court of Bankruptcy to remove a heavy burden from the ordinary courts. Parliamentary Debates (House) May 22, I930, 2045-2046; June $6,1930,2547-2550$. This new court, though a specialized tribunal, is a chapter III court with a life tenure. It is probable, of course, that Parliament, if it wished, could create a non-chapter III court to deal with bankruptcy under $\$ 5 I$ (xvii) of the Constitution.

${ }^{0}$ Robson, Justice and Adacinrstrative Law (1928) ; Dickinson, ADarinistratrve Justice aND the Supremacy of Law (I927); Dickinson, $J$ udicial Control of Official Discretion (I928) 22 AM. PoL. Scr. REV. 275; FREUND, ET AL, The Growth of American Administrative Law (r923); Laski, Gramitar of Politics, (1925) 301, 389 et seq.; Tennant, Administrative Finality (1928) 6 CAN. BAR REV. 497; Lourie, Administrative Law in South Africa (1927) 44 So. AFr. L. J. Io. 
practical expedients for enabling governments to exercise a positive and expanding control over an increasingly complex economic society. With one or two exceptions, all the tribunals heretofore discussed have been created to deal with matters for which ordinary judicial courts are unsuited: (a) because their procedure is unnecessarily slow and cumbersome; or (b) because the burden of litigation would be too great; or (c) because a specialized knowledge or a specialized procedure, or both, are desirable. ${ }^{97}$

The rapid growth of these tribunals has brought with it, in some instances, the possibility of arbitrary administrative action without judicial review; yet in Australia the right of judicial review has, in respect of most of these tribunals, been carefully preserved, ${ }^{98}$ and no such serious protest against "executive justice" has occurred in that country as in Great Britain. The Australian judges, like those of England and America, have been reluctant to yield vast powers of discretion to executive officers. This is understandable, in part because of their traditional desire to uphold the "rule of law", and in part because such an extension of discretionary power is in some measure a derogation from their own function. They, more readily than the American judges, have abandoned, or at least have learned to qualify, the cherished doctrine which they derived from Montesquieu and Blackstone, perhaps because that doctrine, in its purest form, was never so deeply fixed in their minds. They show little anxiety

\footnotetext{
${ }^{n 7}$ None of these reasons can account for the existence of the Deportation Board. It seems to be thought expedient to give finality to the decisions of the administrative department in deportation cases, on the ground that matters of public policy are involved which are outside the domain of the courts.

Concluding their chapter on specialized courts, FrankFurTER AND LANDIS, op. cit. supra note 6, at I86, say: "The need for a coherent system of administrative law, for uniformity and despatch in adjudication, for the subtle skill required by judges called upon to synthesize the public and private claims peculiarly involved in administrative litigation, these and kindred considerations will have to be balanced against the traditional hold of a single system of courts, giving a generalized professional aptitude to its judges and bringing to the review of administrative conduct a technique and a temperament trained in litigations between private individuals."

${ }^{28}$ While there is no review of the decisions of the Minister in deportation cases, a slight safeguard against arbitrary action is evidently intended in the provision that the Chairman of the Deportation Board shall be, or have been, a judicial officer. See $\$ 8 \mathrm{~A}(3)$ of the Immigration Act of I9OI-I920, and the discussion in the Parliamentary Debates, (Senate) Mar. 25, I920, 786-788.
} 
nowadays when a new instrument of government cannot be fitted precisely into one of the three traditional categories. That is a good sign, because, under the conditions of modern life, what Mr. Justice Higgins once referred to as "the interdependence of the arms of government" will increase rather than decrease. Unless the new tribunals have the protection of the judiciary, administration will be seriously hampered and the ordinary courts will be overburdened with unnecessary litigation. 